\title{
Identification of Tumor-Associated Proteins in Oral Tongue Squamous Cell Carcinoma by Proteomics
}

\author{
Qing-Yu He ${ }^{1,2}$, Jia Chen ${ }^{3}$, Hsiang-Fu Kung ${ }^{3}$, Anthony Po-Wing Yuen ${ }^{4}$ \\ and Jen-Fu Chiu ${ }^{2,3}$ \\ ${ }^{1}$ Department of Chemistry, ${ }^{2}$ Open Laboratory of Chemical Biology of the Institute of \\ Molecular Technology for Drug Discovery and Synthesis, ${ }^{3}$ Institute of Molecular Biology, \\ ${ }^{4}$ Department of Surgery, University of Hong Kong, Hong Kong, China
}

Running title: Proteomics of Tongue Squamous Cell Carcinoma

Correspondence to: Dr. Qing-Yu He, Department of Chemistry, University of Hong Kong, Pokfulam, Hong Kong, China. Tel: (852)2299-0787, Fax: (852)2817-1006, E-mail: qyhe@hku.hk

\section{List of Abbreviations:}

UADTSCC, upper aerodigestive tract squamous cell carcinoma; MS, mass spectrometry; MALDI-TOF, matrix-assistant laser desorption/ionization - time of flight; IEF, isoelectric focusing; IPG, immobilized $\mathrm{pH}$ gradient; TC, tumor center; SM, surrounding histologically normal mucosa; MHC \& MLC, myosin heavy and light chain; HSP, heat shock protein.

Keywords: 2D-PAGE, tongue cancer, protein profile, MS fingerprinting 


\section{Summary}

Oral tongue carcinoma is common, particularly in chronic smokers, drinkers and betal squid chewers. This is an aggressive tumor in which patients often present in late stage and have high recurrence rate after treatment. In this article, we report the first proteomic analysis of oral tongue carcinoma to globally search for the tumor-related proteins. Apart from helping us to understand the molecular pathogenesis of the tumor, these proteins may also have potential clinical applications as biomarkers in the surveillance of early cancers of high-risk persons, the treatment response prediction and the detection of residual or recurrent carcinoma after treatment. The protein expression profiles of ten oral tongue squamous cell carcinomas and their matched normal mucosal resection margins were examined by $2 \mathrm{D}$ gel electrophoresis and MALDI-TOF mass spectroscopy. A number of tumor-associated proteins including HSP60, HSP27, $\alpha$ B-crystalline, ATP synthase $\beta$, calgranulin B, myosin, tropomyosin and galectin 1 have been found consistently and significantly altered in their expression levels in tongue carcinoma tissues, compared with their paired normal mucosae. The expression profile portrays a global protein alteration that appears specific to the oral tongue cancer. The potential of utilizing these tumor-related proteins for screening cancer and monitoring recurrence warrants further investigation. 


\section{Introduction}

Upper aerodigestive tract carcinoma (UADTSCC) is a major public health problem worldwide. Oral tongue carcinoma is one of the common UADTSCC. The genetic pathogenesis is still largely unclear. The clinical diagnostic methods mainly rely on symptoms presentation, physical signs and X-ray examination. Unfortunately, the majority of patients were in the advanced stage at the time of first symptomatic presentation and clinical diagnosis [1-6]. The recurrence rate after treatment increases with stage. For those patients with recurrent carcinoma, further salvage treatment is successful only when the tumors are detected in the early stage. All patients who were not feasible for surgical salvage died of recurrence despite of giving chemotherapy and/or radiotherapy [7,8]. With the present clinical assessment method, half of the patients are not salvageable at the time of diagnosis of recurrence and another quarter of patients fail to respond to the salvage treatment because of the advanced stage of recurrence. Obviously, a better method for screening UADTSCC and an early detection of residual or recurrent tumor after treatment are necessary to improve the curative rate.

Proteomics is a powerful analytic technology newly developed to enhance our study on the diagnosis, treatment and prevention of human diseases [9-11]. Two-dimensional (2D) gel electrophoresis has been the principal tool in proteomics, which is able to resolve thousands of proteins in one experiment, providing the highest resolution in protein separation. By comprehensively examining the expression profiles of proteins between normal and diseased samples via 2D electrophoresis, proteomics can produce information on new biomarkers, disease-associated targets and the process of pathogenesis. This technique has been extensively employed to investigate various diseases [12-15] but there is currently no report concerning the proteomic study on UADTSCC. In this study, we used 2D electrophoresis to analyze protein samples extracted from oral tongue tumor tissue and 
matched surrounding histologically normal mucosa from surgical specimens. By carefully selecting carcinoma confining to one subsite of the upper aerodigestive tract and patients without any prior radiotherapy and chemotherapy treatment to the tissue, we hope to reduce the tissue variability, avoid treatment-induced effect on protein expression and yield more consistent results. By comparing the protein profiles between tumor and normal samples, we report herein the identification of proteins that were differentially expressed in tumor. Further global characterization of these proteins provides information for better understanding the pathogenesis of tongue cancer and thus help developing new diagnostic and therapeutic strategies. 


\section{Materials and methods}

\subsection{Tissue and sample preparation}

Ten pairs of surgical specimens of primary oral tongue sqaumous cell carcinoma and their matched adjacent normal mucosae were collected from Queen Mary Hospital, the University of Hong Kong, and were stored in deep freezer $\left(-80^{\circ} \mathrm{C}\right)$ until use. The study has been approved by ethnic committee. All patients have sent a consent form to donate tissue and blood for research purpose. There were 5 male and 5 female patients ranging from 29 to 81 year old. The AJCC pathologic stages were 1 T1N0 M0, 7 T2(6N0, 1N2)M0, 2 T3(1N0, 1N2)M0. Table 1 lists detailed histological data for the tissue samples used and Figure 1 is a representative histological picture showing a pair of matched tissue samples side by side. Overall, the tumor specimens contain $64 \pm 22 \%$ tumor cells.

Tissues $(\sim 200 \mathrm{mg})$ were cut into about $2 \mathrm{~mm}^{3}$ in size and were then homogenized with $0.5 \mathrm{ml}$ Lysis Buffer (Reagent 3, Bio-Rad, containing protease inhibitor cocktail, Sigma 8340, DNase I 1 Uunit/ml) for 5 min on ice using a mini-homogenizer. The lysate was spun down at $14,000 \mathrm{rpm}$ for 10 minutes at $4^{\circ} \mathrm{C}$, the supernatant was transferred into another tube, and then ultra-centrifuged at $100,000 \mathrm{~g}$ for 1 hour at $4^{\circ} \mathrm{C}$. The protein concentration of the resulting supernatants was determined by the method of Bradford and the protein samples were stored at $-80^{\circ} \mathrm{C}$ in aliquot.

\subsection{D-gel electrophoresis}

The 2D-gel electrophoresis was carried out with Amersham Biosystems IPGphor IEF and Ettan Dalt six electrophoresis units by following the protocol described previously [16]. Protein samples $(150 \sim 200 \mu \mathrm{g})$ extracted from tumor center (TC) and surrounding histologically normal mucosa (SM) were applied to the 2D gel electrophoresis and run in pair 
side by side. Triplicate electrophoresis was performed for each pair sample to ensure the reproducibility. All gels were visualized by silver staining [16].

\subsection{Image analysis and MS peptide sequencing}

Image acquisition and analysis were performed by using an ImageScanner (Amersham) and the ImageMaster 2D Elite software (Amersham) [16]. Comparison was made between gel images of TC and SM samples pair by pair. Normalized volume differences were statistically calculated for all the ten cases. Those consistently and significantly different spots were selected for analysis with MALDI-TOF mass spectrometry. Protein spots were cut out in small pieces and subjected to in-gel tryptic digestion overnight [16]. Peptide mass spectra were recorded and parameters for spectra acquisition were used as stated previously [16]. In database protein matching using MS-Fit (http://prospector.ucsf.edu/), $20 \mathrm{ppm}$ or better mass accuracy and MOWSE scores over 200 were obtained in most of analysis. For those lower mass accuracy and score matching, duplicate or triplicate run and analysis were carried out to ensure the accuracy. 


\section{Results}

\subsection{Sample preparation and protein separation.}

Before applied to 2D-gel separation, proteins were extracted from tissue samples and subjected to concentration determination. Total protein extraction rates have no significant difference between tumor and matched surrounding tissues, with $31.7 \pm 8.5$ and $30.3 \pm 7.5$ $\mu \mathrm{g} / \mathrm{mg}$ respectively for TC and SM samples. Usually $200 \mu \mathrm{g}$ of proteins each sample were used for 2D-gel separation and the proteins were quite evenly distributed in the $18 \mathrm{~cm}$ gel with ranges of $\mathrm{p} I$ 4-10 and MW 6-200kDa. Figure 2 is the typical master gel image for both TC and SM samples side by side. Around 600 protein spots in each gel were detected through ImageMaster software. Some proteins present in train spots, indicating that modified proteins or isoforms were fairly separated by the 2D-gel electrophoresis. Highlighted in squares are the eight areas showing consistent and significant differences at least in nine of the ten cases. Statistic data for these proteins (or the sum of isoforms) were summarized in Table 2 with total normalized volumes (\% Vol) and fold differences between TC and SM samples (for total ten pairs). Roughly, nine proteins (or isoforms) are up-regulated and six proteins (isoforms) are suppressed significantly in tumor tissues.

\subsection{Protein identification.}

Each different protein spot was excised and subjected to in-gel tryptic digestion, MALDITOF mass measurement and database matching. Isoforms that gave an identical primary structure in the protein matching are classified into one protein. Table 3 is the summary for the protein identification, most of the protein matching have high sequence coverage, mass accuracy and MOWSE score.

Figure $3 \& 4$ show the alterations of expression levels for each identified protein between tumor and normal mucosae. Myosin heavy chain 1 (MHC1) and galectin 1 are 
evidently increased $(+5$, and +1.5 folds, respectively) in tumor tissue, whereas myosin light chains (MLC) are dramatically down-regulated ( -5.7 to -11 folds) (Fig. 3 I \& V). MLC has three groups respectively belong to light chain 1, alkali light chain and regulatory light chain from high to lower MW in the gel. In some cases, all the three MLC groups were suppressed to an undetectable level in tumor center tissues. Interestingly, tropomyosin has alterations similar to myosin in expression level. Tropomyosin $\beta$ chain was significantly decreased $(-4.5$ folds) and its lower MW isoform was remarkably increased (+6.1 folds) in tumor (Fig. 3 III). Compared to those in normal mucosa, other proteins consistently showing apparent increase in expression level in tumor samples include heat shock 60k protein (HSP60) $(+2$ folds), heat shock $27 \mathrm{k}$ protein (HSP27) $(+1.5$ folds), nuclear FMRP interacting protein 1 (+1.7 folds), calgranulin B (+1.5 folds) and hemoglobin (+2.1 folds), while proteins considerably suppressed in tumor are ATP synthase $\beta$ chain ( -2.3 folds) and crystalline $\alpha \mathrm{B}$ (-2.9 folds) (Fig. 4). It should be pointed out that almost all these proteins and isoforms have molecular weights matching to their experimental values in gels. The only exception is nuclear FMRP interacting protein 1 ; it has $31.3 \mathrm{kDa}$ in size, the spot that appeared in $15 \mathrm{kDa}$ region obviously is a fragment of the protein. The matched peptides (all in the beginning part of the protein sequence) and sequence coverage in the protein matching justify the assignment. 


\section{Discussion}

Oral tongue squamous cell carcinoma originates from the mucosa layer. Tongue consists largely of skeletal muscle covered by a thin layer of mucosa and submucosa. Pathologic feature of muscular invasion is therefore present in most tongue cancer starting from early stage. Muscular invasion was observed in all tumor specimens in this study. Myosin is the structural component of the muscle cytoskeleton. Myosin modulation participates in the process of epithelial cancer progression [17, 18]. In ras transformed fibroblast cells [19] and muscle cells treated with tumor necrosis factor- $\alpha$ [20] and cancer cachexia [21], both MHC and MLC were significantly suppressed. Our finding of the dramatic decline in MLC expression level in tongue tumor tissue reflects the muscle destruction during cancer invasion and migration process. What surprised us is the fact that, despite of the reduction of MLC, there was substantially increased level of MHC (isoform 1) consistently found in tumor tissue. This unexpected finding has not been previously reported in other cancers, and thus may suggest a pathologic phenomenon specific to oral tongue cancer muscular invasion process. Further study is necessary to elucidate the underlying molecular pathogenesis.

Tropomyosin is a cytoskeletal microfilament binding protein expressed in muscle and non-muscle cells. There are several tropomyosin isoforms, and their expression is known to be associated with cell transformation events. Suppression of high MW isoforms of muscle tropomyosin was commonly observed in malignant tumors such as breast, ovarian and prostate cancer [22]. Interestingly, we found in this study that, accompanying with a substantial suppression of the higher MW tropomyosin $\beta$, a low MW tropomyosin isoform was siginificantly over-expressed in tongue tumor tissue (Table 2). This may indicate that different tropomyosin isoforms perform distinct physiological functions in tissue, resulting in diverse regulation in malignant cells [23-26]. In addition, earlier studies revealed that increased expression of a low MW tropomyosin isoform was correlated to the metastatic 
potential of other tumors such as primary breast carcinoma [27], melanoma [28] and Lewis lung carcinoma [29], a similar finding in this study suggests that the correlation between tropomyosin and metastasis may also play a role in oral tongue cancer.

Another muscle-related protein with altered expression level in tongue tumor is galectin 1 . Galectin 1 , together with galectin 3 , belongs to a family of $\beta$-galactoside-binding animal lectins, which are involved in cell differentiation, morphogenesis, tumor progression and metastasis. Extensive investigation has shown that up-regulation of galectin $1 \& 3$ were found in various carcinomas including colon cancer [30], prostate cancer [31], intrahepatic cholangiocarcinoma [32], bladder transitional-cell carcinoma [33], and head and neck tumors [34-36]. The observed elevated expression of galectin 1 in this report implicates that tongue SCC tumor may share the similar mechanism of malignant progression mediated by galectin in promoting cancer cell invasion and migration. It has been suggested that galectin modulates cell adhesion, regulates cell growth, inhibits apoptosis, and therefore enhances the migratory capabilities of tumor astrocytes and their biological aggressiveness [37-39].

HSP60, HSP27 and alpha B-crystallin are a group of stress-related proteins which expression was considerably altered in tumor tissues. Heat-shock proteins are synthesized by cells in response to heat and other environmental stress. Their expression in cells may have important physiological and pathological implications such as protection, cell proliferation, migration and differentiation and disease prognosis. However, numerous research data from different laboratories indicated that these three HSP proteins were modulated independently in response to stress [22, 40-43]. While the expression of HSP60 and HSP27 was stimulated [22, 44-46], alpha B-crystallin was suppressed [40-43, 47] in various tumors. The current observations on the expression of this group of HSP proteins in tongue tumor (Table 2) are exactly consistent with the published results from studies on other cancers. This confirms that 
the small heat shock protein, alpha B-crystallin, may play a distinctive role in the process of carcinogenesis although it shares structural and functional properties with HSP27.

Calgranulin B, also called S100A9 and MRP14, is a member of S100 calcium-binding protein family predominantly expressed in granulocytes. Its biological functions include the intracellular inhibition of casein kinase II which results in the regulation of cellular transcription and translation and the extracellular chemotactic and cytotoxic activity against bacteria, fungi and tumor cells [48]. Calgranulin B over-expression has been found in colon and colorectal cancers [49-51] and this protein has been identified to be tumor-associated protein [52-54]. The higher expression of calgranulin B in TC samples in this study confirms that this tumor marker is also positively up-regulated in oral tongue cancer. However, previous study using a cDNA array hybridization method revealed that the cDNA level of calgranulin B was much higher in non-malgnant cells than that in tumor cells of nasopharyngeal carcinoma [55]. The reasonable explanation would be that cDNA level may not necessarily reflect protein expression level and the protein expression differs in different tissue types.

ATP synthase $\beta$ chain, the catalytic subunit in the ATP synthase complex, was found being markedly down-regulated in tumor tissue (Table 2). This seems contradictory to the fact that tumor cell growth needs a lot of energy from ATP synthesized by ATP synthase. However, recent studies showed that, while ATP synthase D and E chains increased their expression in lung, liver and thyroid tumors [56-59], ATP synthase $\beta$ in fact decreased its content in hepatocellular carcinoma $[60,61]$. The reduction of ATP synthase $\beta$ was subsequently found to be related to the over-expression of an ATPase inhibitor protein in tumor, which prevents hydrolysis of glycolytic ATP, declines the activity of the ATP synthase and therefore modulates the expression of ATP synthase $\beta$ [60]. The process of oral tongue SCC may share the similar mechanism in this respect. 
The last two proteins that had higher expression levels in tumor samples are nuclear FMRP interacting protein and hemoglobin. The nuclear FMRP interacting protein is a newly discovered RNA-binding protein that interacts with the fragile $\mathrm{X}$ mental retardation protein (FMRP) responsible for the fragile $\mathrm{X}$ syndrome through its silenced expression [62, 63]. There is currently no report concerning the expression of the FMRP interacting protein in tumors. The reason for the up-regulation of this protein in tongue cancer is unclear. On the other hand, the relationship between tissue hemoglobin level and tongue SCC tumor appears indirect. Angiogenesis is one of the important factor to promote tumor growth. Angiogenesis in oral tongue carcinoma is an unfavorable prognostic factor [64-66]. The higher hemoglobin level in tumor tissues compared with normal mucosa is consistent with the higher vascular density of growing tumor in normal tissues.

In summary, we have used proteomic technology to globally analyze tongue SCC cancer for the first time. The elicited identification of tumor-associated proteins, including myosin, tropomyosin, galectin 1, HSP60, HSP27, $\alpha$ B-crystalline, ATP synthase $\beta$ and calgranulin $\mathrm{B}$, and the alterations of these proteins in expression level help us better understand the carcinogenesis of oral tongue cancer. These proteins individually may not be specific to tongue SCC cancer, however, a combinational evaluation integrated with the functions and quantitative changes of these proteins holds a potential to be a unique index for assessing the disease. It is therefore worthwhile to further study the plasma levels of these protein biomarkers for their clinical application in screening cancer and monitoring recurrence after treatment. This possibility is under investigation. 


\section{Acknowledgements}

This work was supported by Hong Kong Research Grants Council Grants HKU 7227/02M (to Q.Y.H.) and HKU 7218/02M (to J.F.C.), the Department of Chemistry, and the Areas of Excellence scheme of Hong Kong University Grants Committee. We thank Ms. Yuan Zhou for technical assistance. 


\section{References}

[1] Yuen, P. W., Lam, K. Y., Chan, A. C., Wei, W. I., Lam, L. K., Am. J Surg. 1998, 175, 242-244.

[2] Yuen, A. P. W., Wei, W. I., Wong, Y. M., Tang, K. C., Chinese Med. J. 1997, 110, 859864.

[3] Yuen, A. P. W., Wei, W. I., Wong, Y. M., Tang, K. C., Head Neck 1997, 19, 583-588.

[4] Yuen, A. P. W., Lam, K. Y., Chan, C. L. A., Wei, W. I. et al., Am. J. Surg. 1999, 177, 90-92.

[5] Yuen, A. P. W., Lam, K. Y., Wei, W. I., Ho, W. K., Am. J Surg. 2000, 180, 139-143.

[6] Yuen, A. P. W., Lam, K. Y., Lam, L. K., Ho, C. M. et al., Head Neck 2002, 24, 513520.

[7] Yuen, A. P. W., Wei, W. I., Lam, L. K., Ho, W. K., Kwong, D., Ann. Otol. Rhino. Laryngol. 1997, 106, 779-782.

[8] Yuen, A. P. W., Wei, W. I., Wong, S. H. W., Ng, R. W. M., Ear Nose Throat J. 1998, 77, 181-184.

[9] Borman, S., Chem. Engineering News 2000, 78, 31-37.

[10] Hunt, D. F., J. Proteome Res. 2002, 1, 15-19.

[11] He, Q. Y., Chiu, J. F., J. Cell. Biochem. 2003, in press.

[12] Jungblut, P. R., Zimny-Arndt, U., Stulik, J., Koupilova, K. et al., Electrophoresis 1999, 20, 2100-2110.

[13] Poon, T. C. W., Chan, A. T. C., Zee, B., Ho, S. K. W. et al., Oncology 2001, 61, $275-$ 283.

[14] Hanash, S. M., Madoz-Gurpide, J., Misek, D. E., Leukemia 2002, 16, 478-485.

[15] Srinivas, P. R., Srivastava, S., Hanash, S., Wright, G. L., Jr., Clin Chem 2001, 47, 19011911.

[16] He, Q. Y., Lau, G. K. K., Zhou, Y., Yuen, S.-T. et al., Proteomics 2003, 3, 666-674.

[17] Zhu, Y., Lin, H., Wang, M., Li, Z. et al., Int. J Oncol 2001, 18, 1299-1305.

[18] Chiavegato, A., Bochaton-Piallat, M. L., D'Amore, E., Sartore, S., Gabbiani, G., Virchows Arch. 1995, 426, 77-86.

[19] Kumar, C. C., Chang, C., Cell Growth Differ. 1992, 3, 1-10.

[20] Cheema, I. R., Hermann, C., Postell, S., Barnes, P., Cytobios 2000, 103, 169-176. 
[21] Diffee, G. M., Kalfas, K., Al Majid, S., McCarthy, D. O., Am. J Physiol Cell Physiol 2002, 283, C1376-C1382.

[22] Alaiya, A. A., Franzen, B., Auer, G., Linder, S., Electrophoresis 2000, 21, 1210-1217.

[23] Braverman, R. H., Cooper, H. L., Lee, H. S., Prasad, G. L., Oncogene 1996, 13, $537-$ 545.

[24] Novy, R. E., Lin, J. L., Lin, C. S., Lin, J. J., Cell Motil. Cytoskeleton 1993, 25, 267-281.

[25] Prasad, G. L., Masuelli, L., Raj, M. H., Harindranath, N., Oncogene 1999, 18, 2027 2031.

[26] Shah, V., Braverman, R., Prasad, G. L., Somat. Cell Mol Genet. 1998, 24, 273-280.

[27] Franzen, B., Linder, S., Uryu, K., Alaiya, A. A. et al., Br. J Cancer 1996, 73, 909-913.

[28] Miyado, K., Kimura, M., Taniguchi, S., Biochem Biophys Res Commun 1996, 225, $427-$ 435.

[29] Takenaga, K., Nakamura, Y., Sakiyama, S., Mol Cell Biol 1988, 8, 3934-3937.

[30] Hittelet, A., Legendre, H., Nagy, N., Bronckart, Y. et al., Int. J Cancer 2003, 103, 370379.

[31] van den Brule, F. A., Waltregny, D., Castronovo, V., J Pathol. 2001, 193, 80-87.

[32] Shimonishi, T., Miyazaki, K., Kono, N., Sabit, H. et al., Hum. Pathol. 2001, 32, 302310.

[33] Cindolo, L., Benvenuto, G., Salvatore, P., Pero, R. et al., Int. J Cancer 1999, 84, 39-43.

[34] Delbrouck, C., Doyen, I., Belot, N., Decaestecker, C. et al., Lab Invest 2002, 82, 147 158.

[35] Chiariotti, L., Berlingieri, M. T., Battaglia, C., Benvenuto, G. et al., Int. J Cancer 1995, 64, 171-175.

[36] Gillenwater, A., Xu, X. C., Estrov, Y., Sacks, P. G. et al., Int. J Cancer 1998, 75, $217-$ 224.

[37] Rabinovich, G. A., Baum, L. G., Tinari, N., Paganelli, R. et al., Trends Immunol. 2002, 23, 313-320.

[38] Camby, I., Belot, N., Lefranc, F., Sadeghi, N. et al., J Neuropathol. Exp Neurol. 2002, 61, 585-596.

[39] Perillo, N. L., Marcus, M. E., Baum, L. G., J Mol Med 1998, 76, 402-412.

[40] Kato, K., Ito, H., Hasegawa, K., Inaguma, Y. et al., J Neurochem 1996, 66, 946-950.

[41] Kato, M., Herz, F., Brijlall, D., Kato, S., Experientia 1994, 50, 479-482. 
[42] Klemenz, R., Scheier, B., Muller, A., Steiger, R., Aoyama, A., Verh. Dtsch. Ges. Pathol. 1994, 78, 34-35.

[43] Hitotsumatsu, T., Iwaki, T., Fukui, M., Tateishi, J., Cancer 1996, 77, 352-361.

[44] Malusecka, E., Zborek, A., Krzyzowska-Gruca, S., Krawczyk, Z., Anticancer Res 2001, $21,1015-1021$.

[45] Trieb, K., Gerth, R., Windhager, R., Grohs, J. G. et al., Immunobiology 2000, 201, 368376.

[46] Michils, A., Redivo, M., Zegers, d. B., V, de, M., V et al., Lung Cancer2001, 33, 5967.

[47] Takashi, M., Sakata, T., Ohmura, M., Kato, K., Urol. Res 1997, 25, 173-177.

[48] Hessian, P. A., Edgeworth, J., Hogg, N., J Leukoc. Biol 1993, 53, 197-204.

[49] Jungblut, P. R., Zimny-Arndt, U., Zeindl-Eberhart, E., Stulik, J. et al., Electrophoresis 1999, 20, 2100-2110.

[50] Stulik, J., Osterreicher, J., Koupilova, K., Knizek et al., Electrophoresis 1999, 20, 10471054.

[51] Stulik, J., Kovarova, H., Macela, A., Bures, J. et al., Clin Chim. Acta 1997, 265, 41-55.

[52] Chaurand, P., DaGue, B. B., Pearsall, R. S., Threadgill, D. W., Caprioli, R. M., Proteomics. 2001, 1, 1320-1326.

[53] Gebhardt, C., Breitenbach, U., Tuckermann, J. P., Dittrich, B. T. et al., Oncogene 2002, $21,4266-4276$.

[54] Arai, K., Teratani, T., Nozawa, R., Yamada, T., Oncol Rep. 2001, 8, 591-596.

[55] Fung, L. F., Lo, A. K., Yuen, P. W., Liu, Y. et al., Life Sci. 2000, 67, 923-936.

[56] Srisomsap, C., Subhasitanont, P., Otto, A., Mueller, E. C. et al., Proteomics. 2002, 2, 706-712.

[57] Ying, H., Yu, Y., Xu, Y., Oncol Res 2000, 12, 485-490.

[58] Chen, J., Gokhale, M., Li, Y., Trush, M. A., Yager, J. D., Carcinogenesis 1998, 19, 2187-2193.

[59] Chen, G., Gharib, T. G., Huang, C. C., Thomas, D. G. et al., Clin Cancer Res 2002, 8, 2298-2305.

[60] Capuano, F., Guerrieri, F., Papa, S., J Bioenerg. Biomembr. 1997, 29, 379-384.

[61] Capuano, F., Varone, D., D'Eri, N., Russo, E. et al., Biochem Mol Biol Int. 1996, 38, 1013-1022.

[62] Bardoni, B., Schenck, A., Mandel, J. L., Hum. Mol Genet. 1999, 8, 2557-2566. 
[63] Bardoni, B., Mandel, J. L., Curr. Opin. Genet. Dev. 2002, 12, 284-293.

[64] Shpitzer, T., Chaimoff, M., Gal, R., Stern, Y. et al., Arch. Otolaryngol. Head Neck Surg. 1996, 122, 865-868.

[65] Mineta, H., Miura, K., Ogino, T., Takebayashi, S. et al., Anticancer Res. 2002, 22, 1039-1044.

[66] Hogmo, A., Kuylenstierna, R., Lindholm, J., Munck-Wikland, E., J. Clin. Pathol. 1999, $52,35-40$. 
Table 1. Patients' information and histological data for the tissue samples used.

\begin{tabular}{|c|c|c|c|c|c|c|c|}
\hline PATIENTS & SEX/AGE & T STAGE & $\begin{array}{l}\text { SAMPLE } \\
\text { PAIRS }\end{array}$ & $\begin{array}{c}\text { TUMOR } \\
\text { CELLS }(\%)\end{array}$ & $\begin{array}{l}\text { NORMAL } \\
\text { MUCOSAL } \\
\text { CELLS }(\%)\end{array}$ & $\begin{array}{l}\text { MUSCLE } \\
\text { CELLS }(\%)\end{array}$ & $\begin{array}{c}\text { CONNECTIVE TISSUE CELLS } \\
\text { LYMPHOCYTES, VESSEL CELLS, } \\
\text { FIBROBLAST }(\%)\end{array}$ \\
\hline 1 & $\mathrm{~F} / 29$ & $\mathrm{~T} 2$ & $\begin{array}{c}\text { Tumor (TC) } \\
\text { Mucosa (SM) }\end{array}$ & $\begin{array}{c}65 \\
0\end{array}$ & $\begin{array}{c}0 \\
100\end{array}$ & $\begin{array}{c}15 \\
0\end{array}$ & $\begin{array}{c}20 \\
0\end{array}$ \\
\hline 2 & $\mathrm{M} / 70$ & $\mathrm{~T} 2$ & $\begin{array}{c}\text { Tumor (TC) } \\
\text { Mucosa (SM) }\end{array}$ & $\begin{array}{c}60 \\
0 \\
\end{array}$ & $\begin{array}{c}0 \\
30 \\
\end{array}$ & $\begin{array}{l}30 \\
20\end{array}$ & $\begin{array}{l}10 \\
50\end{array}$ \\
\hline 3 & $\mathrm{~F} / 62$ & $\mathrm{~T} 2$ & $\begin{array}{c}\text { Tumor (TC) } \\
\text { Mucosa (SM) }\end{array}$ & $\begin{array}{c}60 \\
0 \\
\end{array}$ & $\begin{array}{c}0 \\
20 \\
\end{array}$ & $\begin{array}{c}5 \\
60 \\
\end{array}$ & $\begin{array}{l}35 \\
20 \\
\end{array}$ \\
\hline 5 & $\mathrm{M} / 59$ & T3 & $\begin{array}{c}\text { Tumor (TC) } \\
\text { Mucosa (SM) }\end{array}$ & $\begin{array}{c}90 \\
0\end{array}$ & $\begin{array}{c}0 \\
40\end{array}$ & $\begin{array}{c}0 \\
20\end{array}$ & $\begin{array}{l}10 \\
40\end{array}$ \\
\hline 6 & $\mathrm{M} / 50$ & $\mathrm{~T} 2$ & $\begin{array}{l}\text { Tumor (TC) } \\
\text { Mucosa (SM) }\end{array}$ & $\begin{array}{c}35 \\
0\end{array}$ & $\begin{array}{c}0 \\
30\end{array}$ & $\begin{array}{l}60 \\
60\end{array}$ & $\begin{array}{c}5 \\
10\end{array}$ \\
\hline 7 & $\mathrm{~F} / 81$ & $\mathrm{~T} 2$ & $\begin{array}{c}\text { Tumor (TC) } \\
\text { Mucosa (SM) }\end{array}$ & $\begin{array}{c}50 \\
0 \\
\end{array}$ & $\begin{array}{c}0 \\
20 \\
\end{array}$ & $\begin{array}{c}5 \\
70 \\
\end{array}$ & $\begin{array}{l}45 \\
10 \\
\end{array}$ \\
\hline 10 & $\mathrm{~F} / 59$ & $\mathrm{~T} 2$ & $\begin{array}{l}\text { Tumor (TC) } \\
\text { Mucosa (SM) }\end{array}$ & $\begin{array}{c}70 \\
0 \\
\end{array}$ & $\begin{array}{c}0 \\
40 \\
\end{array}$ & $\begin{array}{l}20 \\
20 \\
\end{array}$ & $\begin{array}{l}10 \\
40\end{array}$ \\
\hline
\end{tabular}

$*$ Relative percentage $(\%)$ of cells was round up to $5 \%$, cells less than $5 \%$ were counted as 0 as the number was too small. 
Table 2: Summary of protein alterations

\begin{tabular}{||l|l|l|l|l|l||}
\hline \hline PROTEIN ID & AREA & $\begin{array}{l}\text { EXPERIMENTAL } \\
\text { MW/PI }\end{array}$ & TC (\% VOL) & SM (\% VOL) & $\begin{array}{l}\text { FOLD } \\
\text { DIFFERENCE }\end{array}$ \\
\hline Myosin heavy chain SM1 & I & $200 \mathrm{kD} / 7.5 \mathrm{pI}$ & $0.997 \pm 0.577$ & $0.200 \pm 0.104$ & +5 \\
\hline Heat shock 60kD protein 1 & II & $65 \mathrm{kD} / 5.2-5.5 \mathrm{pI}$ & $0.320 \pm 0.203$ & $0.162 \pm 0.144$ & +2 \\
\hline ATP synthase $\beta$ chain & II & $56 \mathrm{kD} / 5.0-5.4 \mathrm{pI}$ & $0.372 \pm 0.329$ & $0.840 \pm 0.563$ & -2.3 \\
\hline Tropomyosin $\beta$ chain & III & $39-43 \mathrm{kD} / 4.9 \mathrm{pI}$ & $0.601 \pm 0.312$ & $2.687 \pm 1.088$ & -4.5 \\
\hline Tropomyosin isoform & III & $36 \mathrm{kD} / 4.9 \mathrm{pI}$ & $0.546 \pm 0.327$ & $0.090 \pm 0.055$ & +6.1 \\
\hline Heat shock protein 27 & IV & $30 \mathrm{kD} / 5.8-6.5 \mathrm{pI}$ & $1.153 \pm 0.397$ & $0.790 \pm 0.260$ & +1.5 \\
\hline Myosin light chain 1 & V & $25 \mathrm{kD} / 4.7-5.1 \mathrm{pI}$ & $0.604 \pm 0.509$ & $3.456 \pm 0.862$ & -5.7 \\
\hline Myosin alkali light chain 1 & V & $13-14 \mathrm{kD} / 4.6 \mathrm{pI}$ & $0.238 \pm 0.372$ & $1.543 \pm 0.617$ & -6.5 \\
\hline Myosin regulatory light chain 2 & V & $16-20 \mathrm{kD} / 4.6-5.1 \mathrm{pI}$ & $0.316 \pm 0.242$ & $3.439 \pm 1.449$ & -11 \\
\hline Galectin 1 & V & $12-13 \mathrm{kD} / 4.9-5.3 \mathrm{pI}$ & $1.981 \pm 0.971$ & $1.308 \pm 0.289$ & +1.5 \\
\hline Crystallin $\alpha$ B (HSP20 like-protein) & VI & $22-23 \mathrm{kD} / 6.7-7.3 \mathrm{pI}$ & $0.345 \pm 0.362$ & $0.994 \pm 0.328$ & -2.9 \\
\hline Nuclear FMRP interacting protein 1 & VII & $15 \mathrm{kD} / 6.3 \mathrm{pI}$ & $1.096 \pm 0.366$ & $0.647 \pm 0.319$ & +1.7 \\
\hline Calgranulin B & VII & $14 \mathrm{kD} / 5.5 \mathrm{pI}$ & $0.774 \pm 0.398$ & $0.546 \pm 0.140$ & +1.5 \\
\hline Hemoglobin & VIII & $15.9 \mathrm{kD} / 8.2 \mathrm{pI}$ & $6.336 \pm 4.259$ & $3.041 \pm 2.068$ & +2.1 \\
\hline
\end{tabular}

* SM: Surrounding mucosa; TC: Tumor center. 
Table 3. Results of MALDI-TOF mass spectra and database searching for protein identification.

\begin{tabular}{||l|l|l|l|l||}
\hline PROTEIN ID & $\begin{array}{l}\text { PEPTIDES } \\
\text { MATCHED }\end{array}$ & $\begin{array}{l}\text { SEQUENCE } \\
\text { COVERAGE }\end{array}$ & $\begin{array}{l}\text { MASS } \\
\text { ACCURACY }\end{array}$ & $\begin{array}{l}\text { MOWSE } \\
\text { SCORE }\end{array}$ \\
\hline Myosin heavy chain SM1 & 24 & $16 \%$ & $41 \mathrm{ppm}$ & 3528 \\
\hline HSP60 (chaperonin) & 5 & $12 \%$ & $20 \mathrm{ppm}$ & 241 \\
\hline ATP synthase $\beta$ chain & 13 & $31 \%$ & $6 \mathrm{ppm}$ & 20830 \\
\hline Tropomyosin $\beta$ chain & 14 & $46 \%$ & $25 \mathrm{ppm}$ & 771 \\
\hline Tropomyosin isoform & 18 & $47 \%$ & $10 \mathrm{ppm}$ & 2121 \\
\hline Heat shock protein 27 & 11 & $59 \%$ & $12 \mathrm{ppm}$ & 3207 \\
\hline Myosin light chain 1 & 10 & $51 \%$ & $11 \mathrm{ppm}$ & 3527 \\
\hline Myosin alkali light chain & 10 & $45 \%$ & $13 \mathrm{ppm}$ & 3920 \\
\hline $\begin{array}{l}\text { Myosin regulatory light } \\
\text { chain 2 }\end{array}$ & 7 & $42 \%$ & $5 \mathrm{ppm}$ & 213 \\
\hline Galectin 1 & 5 & $41 \%$ & $17 \mathrm{ppm}$ & 41 \\
\hline $\begin{array}{l}\text { Nuclear FMRP interacting } \\
\text { protein 1 }\end{array}$ & 5 & $13 \%$ & $8 \mathrm{ppm}$ & 23 \\
\hline Calgranulin B & 11 & $84 \%$ & $13 \mathrm{ppm}$ & 1122 \\
\hline $\begin{array}{l}\text { Crystallin } \alpha \text { B (HSP20 like- } \\
\text { protein) }\end{array}$ & 13 & $51 \%$ & $20 \mathrm{ppm}$ & 3770 \\
\hline $\begin{array}{l}\text { Hemoglobin } \beta \text { chain } \\
\text { Hemoglobin } \alpha \text { chain }\end{array}$ & 11 & $77 \%$ & $14 \mathrm{ppm}$ & 1126 \\
\hline \hline
\end{tabular}

* SM: Surrounding mucosa; TC: Tumor center. 


\section{Figure Legends}

Figure 1. Representative histological picture showing a pair of matched tissue specimens side by side.

Figure 2. Representative master 2D-gel images of tumor center and surrounding mucosa samples. Highlighted in squares are the eight areas showing significant and consistent differences in protein expression level.

Figure 3. Patterns of protein alterations in Area I, III and V. MHC \& MLC: myosin heavy and light chains.

Figure 4. Protein alterations in Areas II, IV, VI, VII and VIII. 
Normal tongue mucosa

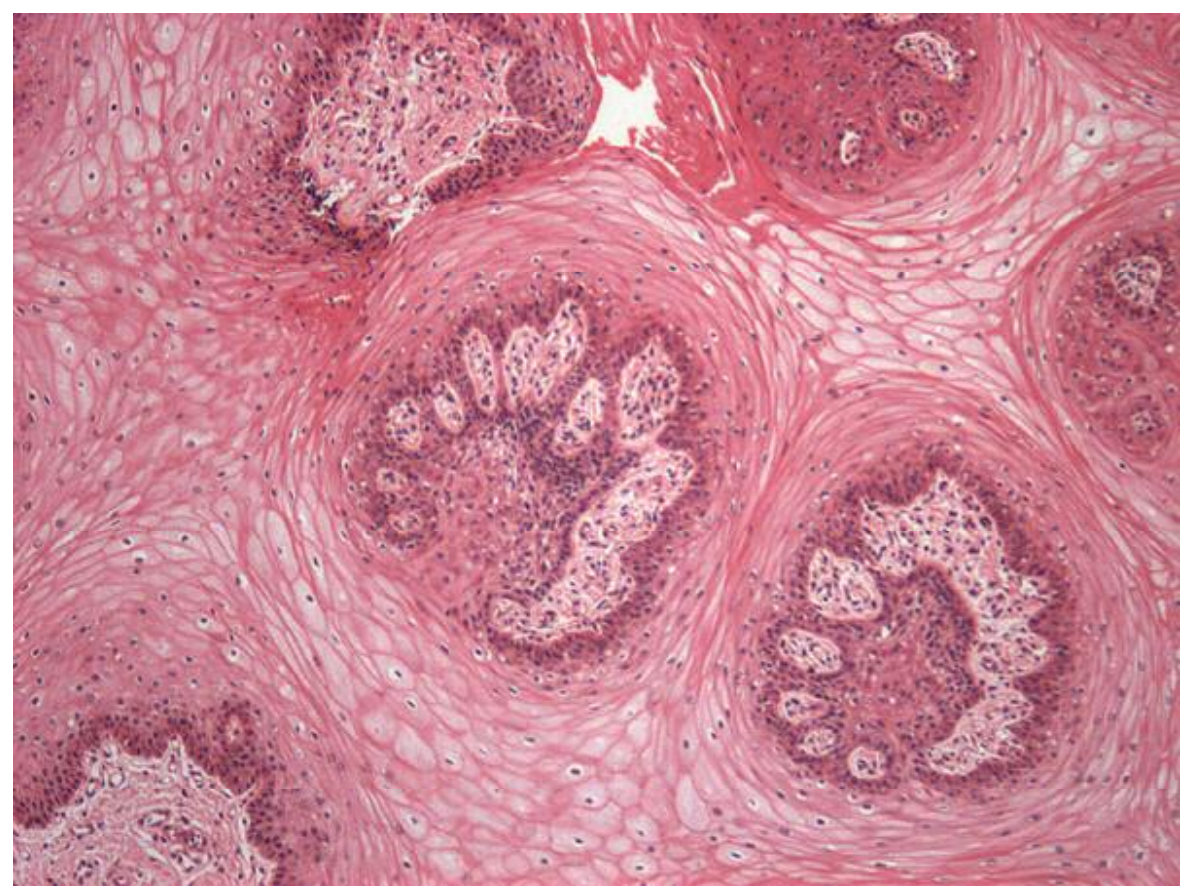

Tongue tumor center

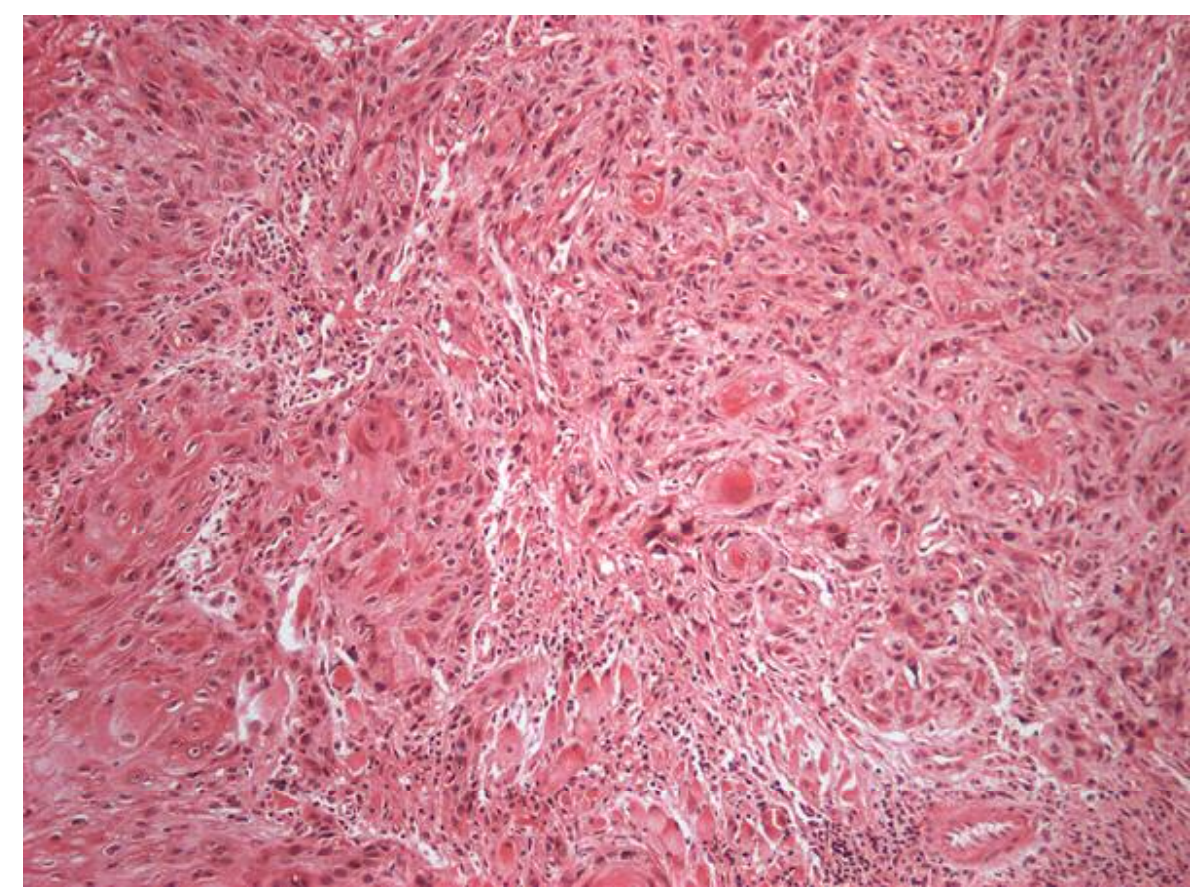

Figure 1 


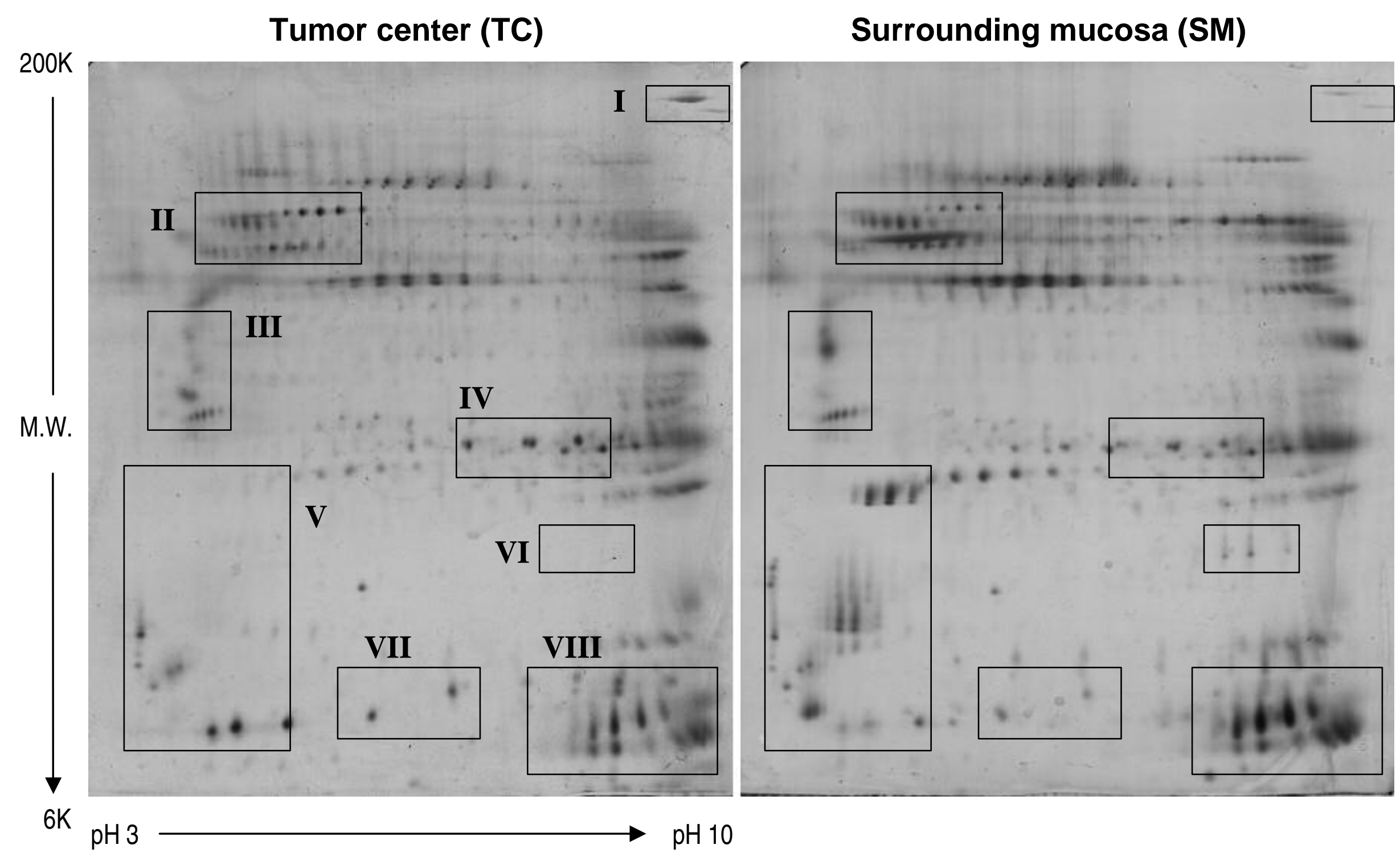




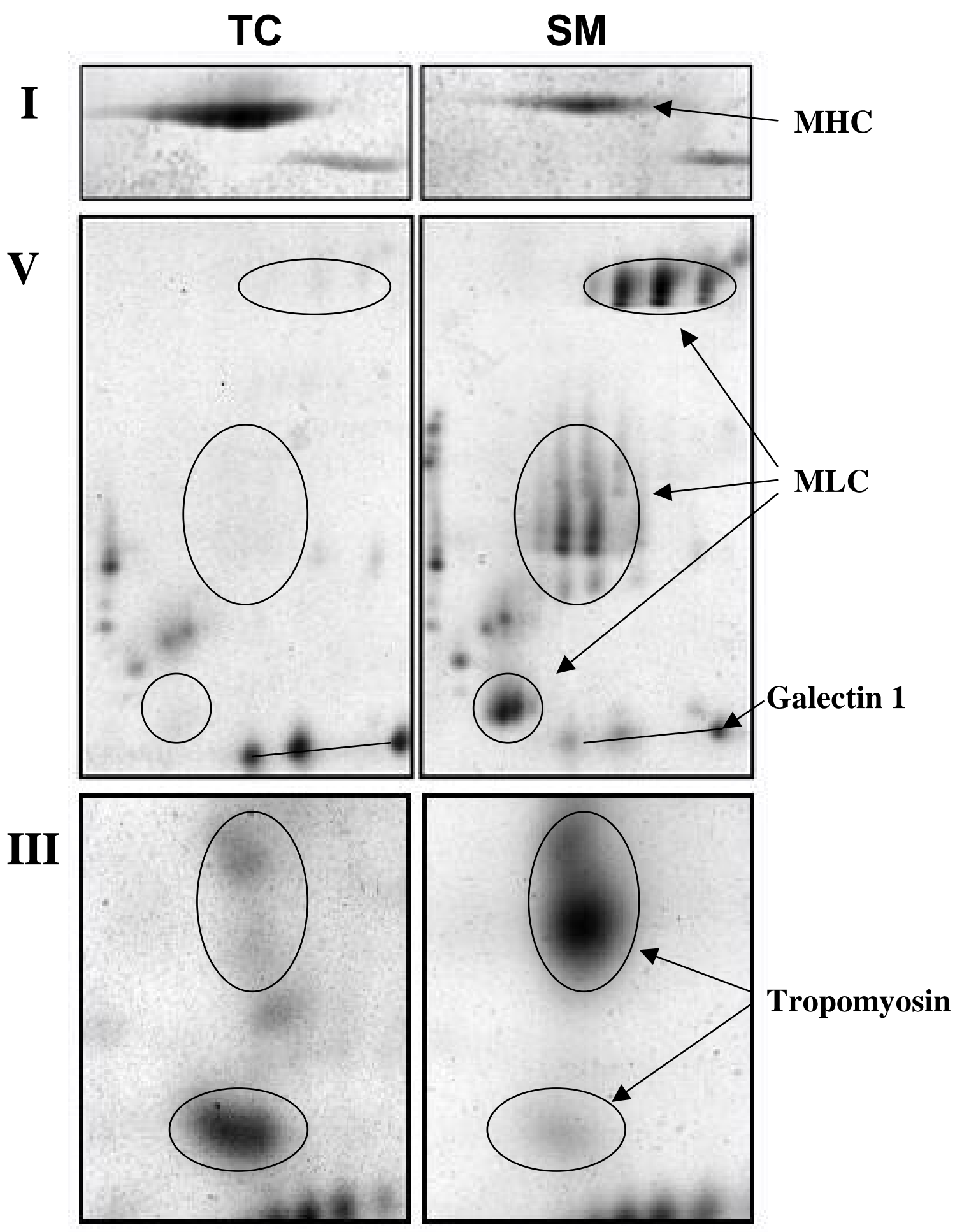




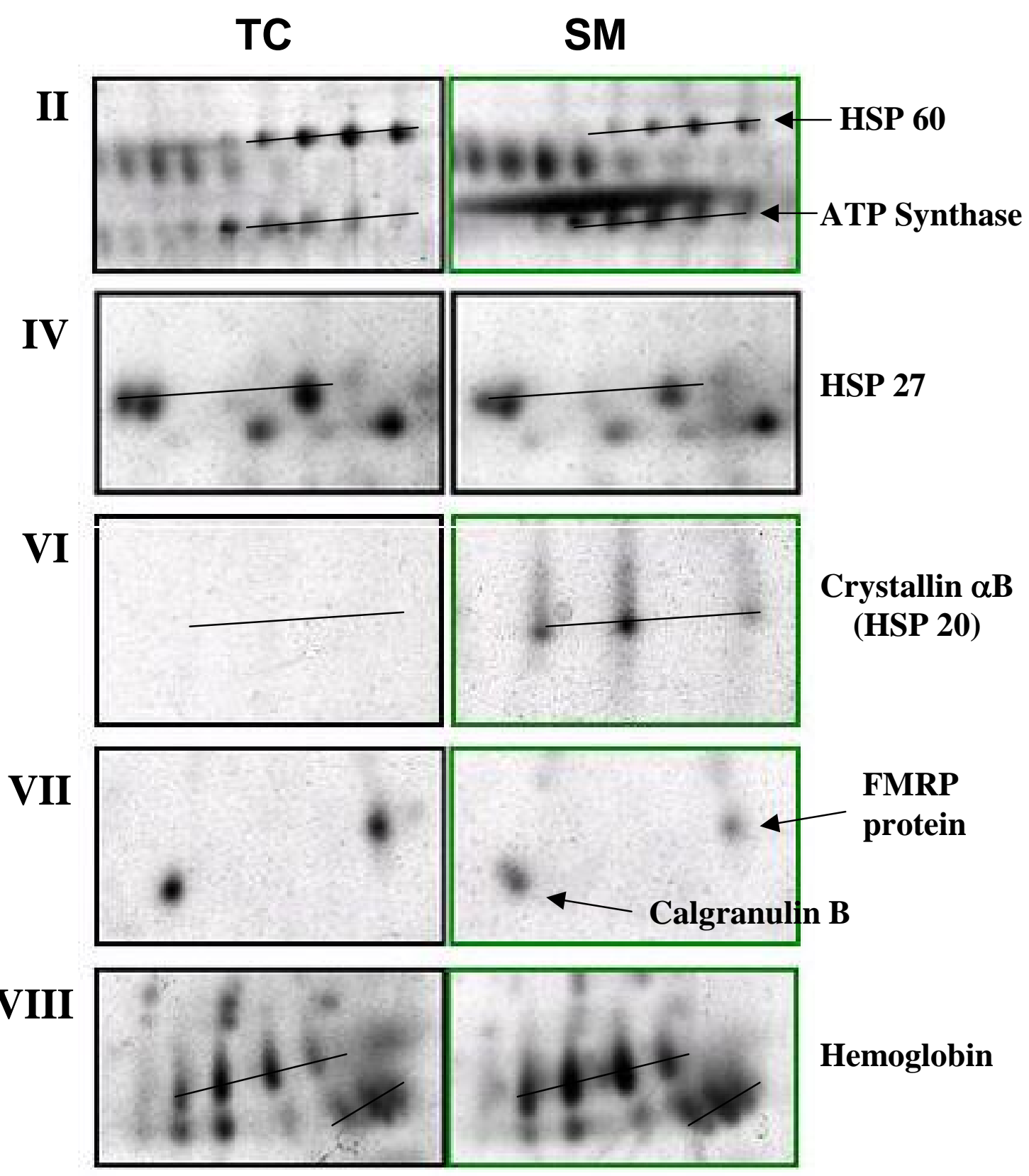

